von Münchhausen (1720-1797, Bodenwerder, Germany), called the lying baron (Lügenbaron), whose name has been given to this syndrome. The Baron himself would smile at reading his name 'Munchausen' in the English literature, mutilated as it is (the meaning being 'house of the monk'). But I think he deserves nevertheless a correct citing of his name, he who during his lifetime was not a decided fan of truth.

Arzt für Neurologie und Psychiatrie

REINHARD ODY

Leitender Abteilungsarzt Psychomedizinische

Abteilung

Marien-Hospital Euskirchen

\section{Community Treatment Orders}

SIR: I wish to echo Dr Hardman's recommendation (Journal, May 1993, 162, 710) that scrutiny of the Victorian Community Treatment Order (CTO) system be made in order that its applicability in England be clarified. I agree that the CTO is not used a great deal - the service in which I work has a catchment population of 210000 and geographically covers $20 \%$ of the State, but has only 31 such Orders at the time of writing. It is the experience of most of our community psychiatric nurses that the CTO is indeed useful as a 'persuader' where depot neuroleptics are concerned, and this service has also found it useful in the placement of longer stay, institutionalised individuals into a community residential programme.

The actual practical usefulness of the CTO when its role as a persuader is insufficient - that is, when a person is, for example, still refusing his/her medication - is a more difficult issue. The main legal redress offered in these circumstances is revokation or return to hospital as an involuntary patient.

While there is nothing in the law to prevent an injection being given by force in a patient's own home, the practical reality is that most nurses are reluctant to do this, given its potential personal risk and the chances of significant damage to the therapeutic relationship. In practice, then, the CTO is revoked for a period of time long enough to remove the patient to hospital, to give the injection, and to return the patient home. While this is cumbersome in terms of paperwork, it does at least assure us that adequate treatment will be delivered, and is practically a far better arrangement than the English Guardianship Order, which can direct a patient to attend for treatment but places no onus on the patient to take it.

The CTO is, of course, no substitute for adequate patient and carer education and appropriate compliance training. Rather, it is an augmentation to other more clinically-based concepts of care in the community, as, indeed, is any aspect of the Mental Health Act. In support of Professor Lamb's (Journal, May 1993, 162, 587-592) assertion that "the chronically mentally ill ... need asylum and sanctuary in the community", a CTO is likely to ensure they have treatment as well.

\section{Hobson Park Hospital \\ Hazelwood Road \\ Traralgon, Victoria}

Graham RidLey

\section{Mania and Down's syndrome}

SIR: Drs Cooper \& Collacott (Journal, June 1993, $162,739-743)$ are incorrect in stating "There have been no reported cases of mania in women with Down's syndrome". Haeger (Journal, July 1990, 157, 153) reported a case of recurrent mania in a 46-yearold woman; her first episode occurring at the age of 32 years. Table 1 requires amending to include this case.

If the case reported by Haeger is incorporated with those reviewed by the above authors, there have then been eight reported cases of mania in people with Down's syndrome, seven male and one female, the mean age of first manic episode is corrected to 33.4 years, and the length of follow-up from first episode to time of report becomes $1-14$ years.

Subsequent amendments of symptom frequency (Table 2) include an increase by a factor of one of elated mood, pressure of speech, sleeplessness, sexual inhibition, physical aggression, and possibly grandiose ideas. Long-term prophylaxis was addressed using maintenance promazine.

The author recommends that all review articles state their source of reference information, thereby allowing an assessment of the accuracy of the data collection to be made and prevention of subsequent publication of inaccurate information.

University of Birmingham

V. P. Prasher

Birmingham B15 $2 Q Z$

\section{Low serum cholesterol and serotonin receptor} subtypes

SIR: We read with interest the article by Hawton et al about low serum cholesterol and suicide (Journal, June 1993, 162, 818-825). One of the main concerns of the authors is the lack of available in vivo data about the effects of low serum cholesterol on serotonin receptor subtypes which are especially involved 